\title{
PERBEDAAN MODEL PEMBELAJARAN PROBLEM BASED LEARNING (PBL) DENGAN PROBLEM SOLVING TERHADAP PRESTASI BELAJAR FISIKA
}

\author{
Elisabeth Tai ${ }^{1}$, Akhmad Jufriadi ${ }^{2}$, Hestiningtyas Yuli Pratiwi ${ }^{3}$ \\ Program Studi Pendidikan Fisika, Universitas Kanjuruhan Malang 1,2,3 \\ e-mail : albertusadonara@gmail.com
}

\begin{abstract}
Abstrak. Tujuan dari penelitian ini antara lain adalah (1) Mengetahui perbedaan model pembelajaran Problem Based Learning (PBL) dibandingkan dengan model pembelajaran Problem Solving dalam pencapaian prestasi belajar fisika. (2) Mengetahui efektifitas penggunaan model pembelajaran Problem Based Learning $(P B L)$ dan Problem Solving terhadap prestasi belajar fisika. Jenis penelitian ini adalah quasi experiment dengan posttest-only control design yang terdiri dari dua variable bebas dan satu variable terikat. Variable bebas adalah perbedaan model pembelajaran Problem Based Learning dan model pembelajaran Problem Solving sedangkan variable terikat adalah prestasi belajar. Populasi penelitian ini adalah seluruh siswa kelas X salah satu SMK Negeri di kota Malang. Penelitian ini menggunakan simple random sampling. Setelah dilakukan random dihasilkan kelas X MM-2 sebagai kelas eksperimen (28 siswa) dan kelas X MM-3 sebagai kelas control (32 siswa). Kelas eksperimen diberikan perlakuan berupa pembelajaran Problem Based Learning (PBL) sedangkan kelas control dengan Problem Solving. Data dikumpulkan dengan soal posttest. Data posttest dianalisis dengan menggunakan statistic ANOVA dengan taraf signifikan 5\%. Hasil penelitian menunjukan nilai rata-rata post-test kelas eksperimen Problem Based Learning sebesar 78,75 dan kelas kontrol Problem Solving sebesar 72. Selisih nilai rata-rata post-test antara kedua kelas tesebut adalah 6,75. Selain itu uji hipotesis dengan ANOVA hasil yang diperoleh signifikansi sebesar $0,003<0,05$ yang berarti $\mathrm{H}_{0}$ ditolak karena sig. $<0,05$. Berdasarkan hasil penelitian dapat disimpulkan bahwa ada perbedaan prestasi belajar yang signifikan pada mata pelajaran Fisika yang pembelajarannya menggunakan model Problem Based Learning dengan pembelajarannya yang menggunakan model Problem Solving dan pembelajaran yang menggunakan model pembelajaran Problem Based Learning lebih efektif dibandingkan dengan menggunakan model pembelajaran Problem Solving.
\end{abstract}

Kata Kunci : Problem Based Learning; Problem Solving; Prestasi Belajar

\section{PENDAHULUAN}

Pendidikan adalah sebuah proses yang melibatkan banyak sumber daya, baik sumber daya manusia, sumber daya dana maupun sumber daya sarana dan prasarana. Setiap sumber daya tersebut melibatkan banyak variabel dan setiap variabel masih melibatkan banyak unsur pula. Dalam menelaah peningkatan mutu pendidikan ada salah satu pendekatan yang harus dilalui dengan sukses, yaitu: pendekatan substansial pendidikan (content approach). Pendekatan ini berkaitan langsung dengan mutu pendidikan dan tingkah laku yang harus dimiliki oleh anak didik, karena proses belajar mengajar ditentukan dengan orientasi pendidikan yang tidak di dominasi oleh guru (teacher centered), melainkan didominasi oleh peserta didik (student centered). Sehingga prestasi peserta didik akan menjadi asli atau tidak artifisial belaka. Prestasi yang diperoleh peserta didik hendaknya dari proses pembelajaran maupun belajar dan tidak hanya melalui transfer infomasi begitu saja (Aedy, 2009). Pemikiran tentang belajar mengacu pada proses, (1) belajar tidak hanya sekedar menghafal, siswa harus mengkonstruksi pengetahuan dibenak mereka sendiri; (2) anak belajar dari mengalami, anak mencatat sendiri pola-pola bermakna dari pengetahuan baru, dan bukan diberi begitu saja oleh guru; (3) 
pengetahuan yang dimiliki seseorang itu terorganisasi dan mencerminkan pemahaman yang mendalam tentang sesuatu persoalan (subject matter); (4) pengetahuan tidak bisa dipisahpisahkan, tetapi mencerminkan keterampilan yang dapat diterapkan; (5) manusia mempunyai tingkatan yang berbeda dalam menyikapi situasi baru; (6) siswa perlu dibiasakan memecahkan masalah menemukan sesuatu yang berguna bagi dirinya, dan bergelut dengan ide-ide; (7) proses belajar dapat mengubah struktur otak, dan perubahan struktur otak itu berjalan terus seiring dengan perkembangan organisasi pengetahuan dan keterampilan seseorang (Syaiful, 2008).

Bruner (dalam Dahar, 1989), menganggap bahwa belajar penemuan sesuai dengan pencarian pengetahuan secara aktif oleh manusia akan memberikan hasil yang lebih baik. Pebelajar berusaha sendiri untuk mencari pemecahan masalah serta pengetahuan yang menyertainya, sehingga menghasilkan pengetahuan yang benar-benar bermakna. Belajar dengan penemuan menunjukan beberapa kebaikan: pertama, pengetahuan itu bertahan lama atau lama diingat, kedua hasil belajar penemuan mempunyai efek transfer yang lebih baik dari pada hasil belajar lainnya dan ketiga, secara menyeluruh belajar penemuan dengan pemecahan masalah dapat meningkatkan penalaran siswa dan kemampuan untuk berpikir secara bebas dengan kata lain belajar penemuan melatih keterampilan kognitif siswa untuk menemukan dan memecahkan masalah tanpa bantuan orang lain.

Ada beberapa perbedaan prestasi belajar siswa yang di temukan oleh Lestari (2012) dalam penelitiannya antara lain: (1) Siswa yang mengikuti model pembelajaran problem based learning dengan siswa yang mengikuti model pembelajaran konvensional dengan nilai $\mathrm{F}=$ 45,372 dan angka signifikansi 0,001 ( $\mathrm{p}<0,05)$, (2) Siswa yang memiliki motivasi belajar tinggi dengan yang memiliki motivasi belajar rendah dengan nilai $\mathrm{F}=5,382$ dengan angka signifikansi $0,023$ ( $\mathrm{p}<0,05),(3)$ terdapat pengaruh interaktif antara model pembelajaran dan motivasi belajar tehadap prestasi belajar fisika dengan nilai $\mathrm{F}=12,206$ dengan taraf signifikansi $0,001(\mathrm{p}<0,05)$, (4) Prestasi belajar fisika antara kelompok PBL dengan kelompok konvensional pada siswa yang motivasi belajarnya tinggi dengan nilai $\mathrm{F}=56,211$, taraf signifikansi 0,001 ; (5) Prestasi belajar fisika antara kelompok PBL dengan kelompok konvensional pada siswa yang motivasi belajarnya rendah dengan nilai $\mathrm{F}=4,916$, taraf signifikansi 0,033 .

Berdasarkan temuan tersebut model pembelajaran berbasis masalah merupakan salah satu model pembelajaran yang memberikan pengaruh positif terhadap peningkatan prestasi belajar fisika terutama bagi siswa yang memiliki motivasi belajar tinggi. Kreativitas siswa meningkat, karena penyampaian masalah secara terbuka dan siswa bertanggung jawab terhadap pemecahan masalahnya sendiri melalui penemuan dan percobaan.

Berdasarkan hasil penelitian Arfiyani (2013), Hasil penelitian menunjukan bahwa: (1) Penerapan model pembelajaran Problem Solving dilengkapi Macromedia Flash dapat meningkatkan kreativitas siswa pada materi hidrokarbon. Hal ini dapat dilihat dalam siklus I dimana persentase kreativitas siswa tinggi adalah $56,25 \%$ dan meningkat menjadi $78,12 \%$ pada siklus II, (2) Penerapan model pembelajaran Problem Solving dilengkapi Macromedia Flash dapat meningkatkan prestasi belajar siswa pada materi hidrokarbon. Dalam penelitian ini prestasi belajar mencakup dua aspek yaitu, kognitif dan afektif. Persentase prestasi belajar kognitif pada siklus I sebesar $43,75 \%$ meningkat menjadi $71,88 \%$ pada siklus II. Persentase prestasi belajar afektif pada siklus I adalah 72,58\% meningkat menjadi 77,19\% pada siklus II.

Menurut Parker (dalam Huda, 2013:95), model pembelajaran kooperatif adalah pembelajaran dimana para siswa saling berinteraksi dalam kelompok-kelompok kecil untuk mengerjakan tugas akademik demi mencapai tujuan bersama. Model pembelajaran cooperative learning dikembangkan untuk mencapai tiga tujuan penting, yaitu prestasi akademik, toleransi dan penerimaan keanekaragaman, serta pengembangan keterampilan sosial (Arends, 2008:5). Berdasarkan tujuan model pembelajaran kooperatif apabila dilihat dari aspek kognitif dapat dikatakan bahwa interaksi antara siswa didalam kelompoknya akan meningkatkan prestasi belajar.

Sebagai salah satu upaya dalam membantu siswa yang mengalami kesulitan dalam proses pembelajaran mata pelajaran Fisika, peneliti memilih model pembelajaran Problem Based Learning (PBL) dan Problem Solving karena model pembelajaran ini dapat meningkatkan kreatifitas siswa dalam berpikir dan berinteraksi serta menciptakan proses pembelajaran yang menyenangkan sehingga dapat meningkatkan prestasi belajar siswa. 
Dua diantara model pembelajaran kooperatif adalah model pembelajaran Problem Based Learning (PBL) dan Problem Solving. Model Problem Based Learning (PBL) dapat digunakan pada mata pelajaran Fisika karena model ini memiliki kelebihan yaitu PBL merupakan teknik yang cukup bagus untuk lebih memahami pelajaran, PBL dapat menantang kemampuan siswa serta memberikan kepuasaan untuk menemukan pengetahuan baru bagi siswa, PBL dapat meningkatkan aktivitas pembelajaran, melalui PBL bisa memperlihatkan kepada siswa setiap mata pelajaran (matematika, IPA, dan lain sebagainya), pada dasarnya merupakan cara berpikir, dan sesuatu yang harus dimengerti oleh siswa, bukan hanya sekedar belajar dari guru atau bukubuku saja, PBL dianggap lebih menyenangkan dan disukai siswa, PBL dapat mengembangkan kemampuan berpikir kritis, PBL dapat memberikan kesempatan kepada siswa untuk mengaplikasikan pengetahuan yang mereka miliki dalam dunia nyata, PBL dapat mengembangkan minta siswa untuk belajar secara terus-menerus sekalipun belajar pada pendidikan formal telah berakhir. Sedangkan model pembelajaran Problem Solving memiliki kelebihan yaitu Model ini dapat membuat pendidikan disekolah menjadi relevan dengan kehidupan sehari-hari, dapat membiasakan para siswa menghadapi dan memecahkan masalah secara terampil, merangsang pengembangan kemampuan berpikir siswa secara kreatif dan menyeluruh, karena dalam proses belajar siswa banyak melakukan mental dengan menyoroti permasalahan dari berbagai segi dan mencari pemecahan masalah tersebut.

\section{METODE PENELITIAN}

Penelitian ini menggunakan pendekatan kuantitatif, karena dalam menganalisis datadata numeric atau angka yang diolah dengan metode statistic, setelah diperoleh hasilnya, kemudian dideskripsikan dengan menguraikan kesimpulan yang didasari oleh angka yang diolah dengan metode statistic tersebut. Penelitian ini menggunakan perlakuan post-test tetapi tidak mengambil sampel secara random. Perbandingan tergantung pada kelompok-kelompok nonekuivalen (Blessing \& Chakrabarti, 2009 :266). Penelitian ini tidak mengacak kelas-kelas yang telah ada di tempat penelitian sehingga kelompok yang dibandingkan mengambil dari kelaskelas yang telah ada. Desain ini melibatkan dua kelas eksperimen. Satu untuk kelas eksperimen dengan menggunakan model pembelajaran Problem Based Learning dan satu kelas control dengan menggunakan model pembelajaran Problem Solving. Setelah diberikan perlakuan model pembelajaran yang berbeda kedua kelompok diberi post-test untuk mengetahui prestasi belajar siswa.

Pengambilan sampel adalah dengan teknik purposive sampling, yaitu pengambilan sampel dilakukan berdasarkan pertimbangan perorangan atau pertimbangan peneliti. Berdasarkan pertimbangan, sampel diambil dengan kesamaan rata-rata hasil belajar siswa. Dengan demikian, subjek penelitian yang dipilih yaitu kelas X MM-2 sebagai kelas eksperimen dan kelas X MM-3 sebagai kelas control. Instrument perlakuan berupa perangkat pembelajaran yang akan digunakan pada kelas eksperimen dengan model pembelajaran Problem Based Learning (PBL) dan kelas kontrol dengan model pembelajaran Problem Solving. Insterumen perlakuan berupa seperangkat Rencana Pelaksanaan Pembelajaran (RPP) dan Lembar Kerja Siswa (LKS). Instrumen pengukuran dalam bentuk tes yang digunakan untuk mengukur prestasi fisika yaitu bentuk tes objektif (pilihan ganda) sebanyak 15 butir soal yang disusun berdasarkan tujuan pembelajaran fisika yang terdapat dalam RPP. Teknik analisis data menggunakan Uji Statistik ANOVA dengan taraf signifikan 0.05 dan analisis data akan dilakukan dengan bantuan program SPSS 16.0 for Windows.

\section{HASIL DAN PEMBAHASAN}

Deskripsi hasil tes prestasi belajar pada materi pokok Hukum Archimedes berdasarkan pembelajaran disajikan pada tabel 1 .

Tabel 1. Hasil Tes Prestasi belajar

\begin{tabular}{llllll}
\hline Kelompok & Model & \multirow{2}{*}{ Jml Sampel } & \multicolumn{2}{l}{ Nilai Prestasi } & Rata-Rata \\
\cline { 3 - 6 } & & & Tertinggi & Terendah & \\
\hline Eksperimen & PBL & 28 & 93 & 60 & 78.75 \\
\hline Kontrol & PS & 32 & 86 & 53 & 72 \\
\hline
\end{tabular}


Berdasarkan tabel 1 nilai prestasi belajar pada kelompok eksperimen yaitu dengan menggunakan model pembelajaran Problem Based Learning dengan jumlah sampel 28, nilai tertinggi 93 dan nilai terendah 60 dengan rata-rata pada kelas eksperimen yaitu 78,75. Sedangkan nilai prestasi belajar pada kelompok control yaitu dengan menggunakan model pembelajaran Problem Solving dengan jumlah sampel 32, nilai tertinggi 86 dan nilai terendah 53 dengan rata-rata pada kelas control yaitu 72. Dengan demikian nilai prestasi belajar siswa pada kelompok eksperimen lebih tinggi dari kelompok kontrol.

Namun untuk meyakinkan maka dilakukan pengujian hipotesis menggunakan Uji ANOVA. Hasil yang diperoleh signifikansi sebesar $0,003<0,05$ yang berarti $\mathrm{H}_{0}$ ditolak karena sig. $<0,05$, maka dapat disimpulkan bahwa ada perbedaan prestasi belajar yang signifikan pada mata pelajaran Fisika yang pembelajarannya menggunakan model Problem Based Learning dengan pembelajarannya yang menggunakan model Problem Solving dan pembelajaran yang menggunakan model pembelajaran Problem Based Learning lebih efektif dibandingkan dengan menggunakan model pembelajaran Problem Solving. Kemampuan awal yang dilihat dari pretest antara kelas eksperimen Problem Based Learning dengan kelas kontrol Problem Solving relatif sama. Hal tersebut dapat dilihat pada nilai rata-rata pre-test yang diperoleh, yaitu rata-rata kelas eksperimen Problem Based Learning sebesar 62,48 dan kelas kontrol Problem Solving sebesar 34,73. Selisih nilai rata-rata pre-test kelas eksperimen Problem Based Learning dengan kelas kontrol Problem Solving hanya sebesar 5,32. Nilai rata-rata post-test kelas eksperimen Problem Based Learning sebesar 78,75 dan kelas kontrol Problem Solving sebesar 72,00. Selisih nilai rata-rata antara kelas eksperimen Problem Based Learning dengan kelas kontrol Problem Solving sebesar 6,75. Adanya perbedaan hasil post-test dikarenakan penerapan model pembelajaran pada kedua kelas ini berbeda dan setiap model pembelajaran memiliki keunggulan dan kelemahan masing-masing. Dengan demikian dapat disimpulkan bahwa pada kelas eksperimen yang menggunakan model pembelajaran Problem Based Learning lebih efektif dengan hasil yang signifikan jika dibandingkan dengan kelas kontrol yang menggunakan model pembelajaran Problem Solving.

Berdasarkan hipotesis dan analisis data mengenai perbandingan penggunaan model pembelajaran Problem Based Learning dan model pembelajaran Problem Solving terhadap prestasi belajar Fisika siswa kelas X MM di salah satu SMK Negeri kota Malang didapatkan temuan penelitian yaitu ada perbedaan prestasi belajar yang signifikan antara kelas eksperimen yang menggunakan model pembelajaran Problem Based Learning dengan kelas kontrol yang menggunakan model pembelajaran Problem Solving. Hal ini dapat diketahui bahwa kemampuan awal yang dapat dilihat dari nilai pre-test antara kelas eksperimen Problem Based Learning dengan kelas kontrol Problem Solving relatif sama, yaitu selisih nilai rata-rata pre-test hanya sebesar 5,32 dan perbedaan yang signifikan pada selisih nilai rata-rata post-test antara kelas eksperimen Problem Based Learning dengan kelas kontrol Problem Solving yaitu sebesar 6,75. Terdapat perbedaan karena pada model pembelajaran Problem Based Learning dimana tahap awal guru menyampaikan tujuan pembelajaran agar siswa terlibat dalam perumusan masalah. Pada tahap merumuskan masalah guru memberikan masalah kepada siswa, sebelum membuat masalah siswa sudah harus mengetahui konsep terlebih dahulu. Pada tahap ini siswa dilatih untuk mengembangkan pengetahuan awal siswa terhadap materi yang akan dipelajari.

Tahap selanjutnya yaitu guru membantu siswa untuk mendefinisikan dan mengorganisasikan tugas belajar yang berhubungan dengan masalah tersebut. Dalam tahap ini guru turut serta membantu siswa dalam mengorganisasikan siswa. Pada tahap ini, masalah yang berkaitan dengan pokok bahasan Hukum Archimedes tidak hanya disajikan melalui penjelasan atau kata-kata, tetapi masalah disajikan melalui LKS yang diberikan oleh guru kepada siswa. Pada tahap ini siswa secara aktif menyusun rancangan percobaan sendiri dan peran guru sangat sedikit. Tahap selanjutnya yaitu siswa merencanakan dan menyiapkan karya yang sesuai/tepat, seperti laporan, rekaman video dan model-model yang membantu mereka untuk menyampaikannya kepada orang lain. Jadi tahap ini memungkinkan akan muncul berbagai hal yang berbeda antara kelompok yang lainnya karena setiap kelompok akan memiliki pemikiran yang berbeda terkait dengan materi yang akan dipelajari.

Tahapan yang terakhir yaitu guru membantu siswa melakukan refleksi dan evaluasi terhadap penyelidikan/investigasi mereka dan proses-proses yang mereka gunakan. Dalam tahap 
ini merefleksi dan mengevaluasi apakah prosedur yang diterapkan dan hasil yang diperoleh benar, apakah ada prosedur lain yang lebih efektif, apakah prosedur yang dibuat dapat digunakan untuk menyelesaikan masalah sejenis atau apakah prosedur dapat dibuat generalisasinya.

Beberapa temuan pada kelas eksperimen menjelaskan kesulitan siswa saat memahami dan menyelesaikan masalah disebabkan karena pemahaman dan daya analisis siswa terhadap masalah rendah (Selcuk, 2010; Akinoglu dan Tandagon, 2007) sehingga siswa memerlukan waktu yang lama dalam menyelesaikan masalah (Sahin dan Yorek, 2009; Kelly, 2007). Untuk kelas kontrol yang menggunakan model pembelajaran Problem Solving, dimana tahap awal guru merumuskan masalah. Guru memberikan masalah kepada siswa, sebelum membuat masalah siswa harus sudah mengetahui konsep terlebih dahulu. Pada tahap ini siswa dilatih untuk mengembangkan pengetahuan awal siswa terhadap materi yang akan dipelajari. Tahap selanjutnya yaitu guru membantusiswa untuk mendefinisikan dan mengorganisasikan tugas belajar yang berhubungan dengan masalah tersebut. Pada tahap ini guru turut serta membantu siswa dalam mengorganisasikan siswa. Selanjutnya menyusun hipotesis. Pada saat menyusun hipotesis siswa diberikan kesempatan untuk bertanya. Pada tahap ini merupakan tahap penggalian pengetahuan awal siswa. Tahap ini mempunyai kelebihan pada siswa untuk pengembangan keaktifan, membangun keyakinan pribadi dan terjadi transformasi pengetahuan. Tahap selanjutnya yaitu merancang percobaan dan melakukan percobaan. Pada tahap ini siswa di dalam kelompoknya merancang percobaan yang akan dilakukan. Di dalam merancang percobaan guru ikut serta mengarahkan siswa di dalam melakukan diskusi agar tahap-tahap yang dilakukan dalam percobaan terstruktur dan jelas. Langkah terakhir adalah menyimpulkan jawaban yang sudah di uji melalui percobaan dengan hipotesis sebelumnya, dalam hal tersebut akan didapatkan apakah hipotesis mereka ajukan benar atau salah, tentunya dengan tetap didampingi oleh guru.

Pada model pembelajaran Problem Based Learning siswa diberikan kesempatan dalam membangun pengetahuannya. Kesempatan yang dimaksud adalah siswa diberikan kebebasan mengembangkan gagasannya, merancang percobaan, sampai dengan membuat kesimpulan dengan bahasa sendiri dan tentunya dengan pemberian motivasi oleh guru dan dengan arahanan yang tentunya dapat membantu siswa untuk lebih fokus pada topik yang dipelajari. Sedangkan pada model pembelajaran Problem Solving siswa diberikan keluasan pada fokus tertentu saja untuk mengembangkan pengetahuannya. Hal ini akan memungkinkan setiap kelompok memiliki pengetahuan yang terbatas dikarenakan pengetahuan siswa hanya terfokus pada teori saja.

Pada model pembelajaran Problem Based Learning guru mengawasi siswa di dalam pelaksanaan pembelajaran dan membantu siswa apabila terdapat siswa yang mengalami kesulitan. Dalam model pembelajaran Problem Based Learning, suatu permasalahan dikaitkan dengan lingkungan dan keadaan sekitar sehingga siswa mampu berfikir lebih luas dan mampu mengkreasikan ide-idenya lebih luas lagi. Dengan demikian pada model pembelajaran Problem Based Learning siswa lebih terarah di dalam pembelajaran dan pengetahuan yang memiliki antara siswa tidak jauh berbeda atau hamper sama. sedangkan pada Problem Based Learning sangat memungkinkan tingkat pengetahuan yang dimiliki antara siswa dapat sama. Sehingga metode pembelajaran Problem Based Learning lebih baik diterapkan dalam pembelajaran untuk meningkatkan prestasi belajar fisika.

Penelitian Wardana (2010) menunjukkan siswa yang mendapat perlakuan model PBL memiliki kemampuan berpikir tingkat tinggi dan pemahaman konsep fisika lebih baik. Penelitian Merdana (2011) menunjukkan model PBL memberikan hasil kemampuan berpikir kritis siswa yang lebih baik. Hal ini mengindikasikan bahwa dalam pencapaian prestasi belajar yang belajar dengan menggunakan model pembelajaran Problem Based Learning memberikan hasil yang lebih baik dibandingkan dengan siswa yang belajar menggunakan model pembelajaran Problem Solving.

Prestasi Belajar Fisika Yang Menggunakan Model Pembelajaran Problem Based Learning Lebih Efektif Jika Dibandingakan Dengan Yang Menggunakan Model Pembelajaran Problem Solving. Temuan dalam penelitian ini menunjukan bahwa prestasi belajar yang mengguanakan model pembelajaran Problem Based Learning lebih efektif daripada yang menggunakan model pembelajaran Problem Solving. Hal ini dapat ditunjukan dengan rata-rata prestasi belajar siswa 
kelas eksperimen Problem Based Learning lebih tinggi dari siswa kelas kontrol Problem Solving. Rata-rata prestasi belajar FISIKA kelas eksperimen Problem Based Learning setelah mendapat perlakuan adalah 78,75 sedangkan kelas kontrol Problem Solving, prestasi belajar FISIKA setelah mendapat perlakuan adalah 72 .

Berdasarkan hasil analisis data, menunjukan bahwa model pembelajaran Problem Based Learning lebih efektif terhadap prestasi belajar fisika kelas X MM di salah satu SMK Negeri di kota Malang. Hal ini dibuktikan dengan nilai signifikansi sebesar 0,003 $<0,05$. Pembelajaran Problem Based Learning lebih mengutamakan tanggungjawab siswa dalam belajar, penyampaian ide, gagasan dan informasi yang diperoleh kepada teman-teman secara individu, dan dapat memberikan motivasi dan rangsangan kepada siswa untuk berpikir, serta mengajarkan siswa untuk mampu menerima informasi dari teman lain. Dengan adanya siswa yang dapat mengembangkan kemampuan berpikirnya melalui pembelajaran Problem Based Learning secara tidak langsung dapat meningkatkan prestasi belajar siswa. Hal itu sejalan dengan tujuan dari pembelajaran kooperatif yaitu meningkatkan prestasi akademik, penerimaan keanekaragaman, dan peningkatan keterampilan sosial (Arends 2008:5).

Pelakasanaan proses pembelajaran yang menggunakan model pembelajaran Problem Based Learning merupakan salah satu upaya penting untuk memperoleh kemampuan berpikir siswa secara bersama-sama dan pertanggungjawaban pikiran siswa tersebut. Dengan adanya pembelajaran tersebut, maka materi pelajaran yang dipelajari akan lebih mudah dipelajari, dipahami, dihayati, dan diingat dalam waktu yang relatif lama karena pada pembelajaran ini siswa yang mengumpulkan informasi dari pikiran bersama terkait dengan materi yang dipelajari.

\section{KESIMPULAN}

Dengan demikan dapat disimpulkan bahwa ada perbedaan prestasi belajar yang signifikan pada mata pelajaran Fisika yang pembelajarannya menggunakan model Problem Based Learning dengan yang pembelajaran menggunakan model Problem Solving.

Berdasarkan penghitungan rata-rata gain score, rata-rata kelas eksperimen Problem Based Learning sebesar 16,27 dan kelas kontrol Problem Solving sebesar 14,84 maka dapat disimpulkan pada kelas eksperimen yang menggunakan model pembelajaran Problem Based Learning lebih efektif dengan hasil yang signifikan jika dibandingkan dengan kelas kontrol yang menggunakan model pembelajaran Problem Solving apabila dilihat pada prestasi belajar (aspek konitif).

Mengacu pada pembahasan dan hasil penelitian yang telah dilakukan maka saran yang dapat disampaikan adalah sebagai berikut. Bagi guru bidang studi Fisika disarankan untuk menggunakan model pembelajaran Problem Based Learning dan model pembelajaran Problem Solving sebagai salah satu alternative dalam pembelajaran Fisika, karena sudah terbukti dapat meningkatkan prestasi belajar siswa. Bagi kepala sekolah untuk dapat memfasilitasi terlaksananya model pembelajaran Problem Based Learning dan model pembelajaran Problem Solving dengan cara mengadakan pelatihan terkait model-model pembelajaran kooperatif dan model pembelajaran inovatif untuk meningkatkan kualitas sekolah dalam bidang pembelajaran.Bagi peneliti yang akan mengkaji lebih lanjut tentang model pembelajaran Problem Based Learning dan model pembelajaran Problem Solving disarankan untuk melakukan pengujian ulang pada materi lain, diluar cakupan materi pada penelitian sekarang yakni Hukum Archimedes. Selain itu disarankan pula untuk pengembangan model pembelajaran lainnya dengan mengujicobakan kombinasi model pembelajaran yang lebih variatif dan menyiapkan alat praktek yang lebih lengkap sehingga kegiatan ekperimen yang dilakukan dapat berjalan dengan lancar. 


\section{DAFTAR RUJUKAN}

Aedy, Hasan. 2009. Karya agung sang guru sejati. Bandung: Alfabeta.

Ahmadi, Iif Khoiru. 2011. Strategi Pembelajaran Sekolah Terpadu. Jakarta: Prestasi Pustakaraya.

Arends, Richard I. 2008. Learning To Teach: Belajar untuk Mengajar. Yogyakarta: Pustaka Pelajar.

Arfiyani, Afrida Yunia. 2013. Penerapan Model Pembelajaran Problem Solving Dilengkapi Mavcromedia Flash untuk Meningkatkan Kreativitas dan Prestasi Belajar pada Materi Hidrokarbon Siswa Kelas X-5 SMA. (Online). (http://www.jurnal.fkip.uns.ac.id/index.php/kimia/article/view/3312). Diakses tanggal 21 September 2016.

Arifin, Zainul. 2009. Evaluasi Pembelajaran: Prinsip, Teknik, Prosedur. Bandung: Remaja Rosdakarya.

Arikunto, Suharsimi. 2010. Prosedur Penelitian: Suatu Pendekatan Praktik. Jakarta: Rineka Cipta.

Djamarah, Syaiful Bahri. 2012. Prestasi Belajar dan Kompetensi Guru. Surabaya: Usaha Nasional.

Huda, Miftahul. 2013. Cooperative Learning: Metode, Teknik, Struktur dan Model Penerapan. Yogyakarta: Pustaka Pelajar.

Lestari, Ni Nyoman Sri. 2012. Pengaruh Model Pembelajaran Berbasis Masalah (Problem Based Learning) dan Motivasi Belajar Terhadap Prestasi Belajar Fisika bagi Siswa Kelas V11 SMP. (Online). (http://pasca.undiksha.ac.id/ejournal/indeks.php/jurnal_tp/article/view/297/91). Diakses tanggal 19 September 2016.

Made Wena. 2009. Strategi Pembelajaran Inovatif Kotemporer. Jakarta: PT. Bumi Aksara.

Sagala, H. S. 2008. Konsep dan Makna Pembelajaran. Bandung: Alfabeta.

Sugiyono. 2013. Metode Penelitian Kuantitatif Kualitatif dan $R$ dan D. Bandung: Alfabeta.

Suprijono, Agus. Cooperative Learning: Teori dan Aplikasi PAIKEM. Yogyakarta: Pustaka Pelajar.

Susanto, Ahmad. 2013. Toeri Belajar dan Pembelajaran di Sekolah Dasar. Jakarta: Kencana Prenade Media.

Susilana, R dan Riyana, C. 2008. Media Pembelajaran. Bandung: CV Wacana Prima.

Syaiful, S. 2008. Konsep dan makna pembelajaran. Bandung: Alfabeta

Trianto. (2010). Model Pembelajaran Terpadu. Jakarta: Bumi Aksara.

Wina Sanjaya. (2006). Strategi Pembelajaran Berorientasi Standar Proses Pendidikan. Jakarta: Kencana Prenada Media Group.

Yatim Riyanto. (2009). Paradigma Baru Pembelajaran. Jakarta: Kencana Prenada. 